\title{
Ultrastructure Features of Coronary Artery Endothelium in Bactrian Camel (Camelus bactrianus)
}

\author{
Características Ultraestructurales del Endotelio de las Arterias \\ Coronarias en el Camello Bactriano (Camelus bactrianus)
}

\author{
Guoqiang Yuan*; Yawen Pan",**; Haiyan $\mathrm{Li}^{* * * *}$ \& Jianlin Wang ${ }^{* * * * *}$
}

YUAN, G.; PAN, Y.; LI, H. \& WANG, J. Ultrastructure features of coronary artery endothelium in bactrian camel (Camelus bactrianus). Int. J. Morphol., 34(1):280-284, 2016.

SUMMARY: Vascular endothelium play an essential role in regulating endothelial functions by maintaining normal vascular tone, modulating hemostasis, and preventing thromobogenesis. The aim of present study was to reveal ultrastructure features of coronary artery endothelium in Bactrian Camels by means of scanning electron microscope (SEM) technology. The results showed that the endothelial cells distribute along the direction of blood flow. Their morphology and protuberant degree towards luminal surface vary for different parts of the coronary artery. The luminal surface of a.c oronaria sinistra and a. coronaria dextra was covered by impaired and intact endothelium, respectively. Platelets and leukocytes sticking to the endothelium were found.

KEY WORDS: Endothelial cells; Bactrian Camel; Coronary artery; Ultrastructure.

\section{INTRODUCTION}

Bactrian camel is an important species in harsh desert ecological conditions. Despite their valuable use as draft animals, they are also used for milk, meat and fur production (Ji et al., 2009; Chuluunbat et al., 2014). In recent years, the number of Bactrian camels is getting smaller due to environmental changes and disease. In the camel, heart diseases such as pericarditis, vegetative valvular endocarditis and hypertrophic cardiomyopathy had been reported (Bekele, 1999; Al-Ani, 2004; Fowler, 2010). However, cardiovascular diseases were rarely found. The endothelium of coronary arteries has been identified as the important organ that locally regulates coronary perfusion and cardiac function by producing vasoactive substances (Yang, 2014). Damage to the endothelium may predispose the vessel to atherosclerosis and increase the risk for cardiovascular, inflammatory and malignant diseases.

Our previous study had reported the origin, distribution and course of the coronary arteries in Bactrian camels on gross examination (Yuan et al., 2009). However, much less is known of the ultrastructure of the coronary artery endothelium. Considering this, the aim of this study was to clarify endothelium ultrastructure of coronary arteries in this type of animal by using SEM technology.

\section{MATERIAL AND METHOD}

Nine hearts of sexually mature male Bactrian camel were obtained from a slaughter house of the Right Alasan Banner Food Company in Inner Mongolia Autonomous Region, China. Camels were clinically healthy based on physical and laboratory evaluation (normal complete cell blood counts and biochemistry panel).

For examination under SEM vessel sections were fixed using a mixture of $2 \%$ paraformaldehyde and $2.5 \%$ glutaraldehyde, in $0.05 \mathrm{M}$ cacodylate buffer at a $\mathrm{pH}$ 7.4. Subsequently, vessel tissue was fixed in a mixture of $1.6 \%$ $\mathrm{K}_{4} \mathrm{FeCN}_{6}$ and $2 \% \mathrm{O}_{\mathrm{s}} \mathrm{O}_{4}$. After fixing, tissue sections were dehydrated in series of alcohols and acetate solutions, critical-point dried, and prepared to examination in SEM S3400 using standard procedures.

\footnotetext{
Neurology Institute, The Second Hospital, Lanzhou University, Gansu, China.

** Department of Neurosurgery, The Second Hospital, Lanzhou University, Gansu, China.

*** School of Life Science, Lanzhou University, Gansu, China.

This study was funded by the National Natural Science Foundation of China (81341100) and the Natural Science Foundation of Gansu Province (1308RJYA033).
} 


\section{RESULTS}

A. Coronaria sinistra. The endothelium irregularly orientates and morphologically changes in the trunk of a. coronaria sinistra. A large number of deciduous endothelial cells still adhere to the surface of the lumen of the vessel. Neoendothelial cell like a tadpole in shape was also found (Fig. 1A). Area of endothelial damage was detected. In region of the vessel with endothelial denudation the exposure of underlying collagen fibrils was visible (Fig. 1B).

Ramus interventricular paraconoalis is one main branch of a. coronaria sinister. A large number of endothelial cells like fist or papilla in shape distribute along the direction of blood flow and protrude into luminal surface of the vessel.
Most of them align in the same direction, few in the opposite (Fig. 2A). The extended distance of endothelial cells towards the lumen of the vessel was different (from $80 \mathrm{~mm}$ to 240 $\mathrm{mm})$. The endothelium was flat in some region. Collagen tiers covering the surface of the lumen of the vessel were found (Fig. 2B).

Ramus circumflex sinistra is another important branch of a. coronaria sinistra. Endothelial cells like convex papillate distribute along the groove of the vessel (Fig. 3A). Oval or circular leukocytes adhering to endothelium are visible (Fig. 3B).

A. coronaria dextra. The endothelium is comparatively flat and smooth in the trunk of a. coronaria dextra (Fig. 4A). Few polygonal and flabellate endothelial cells protruding into the lumen of the vessel (Fig. 4B).
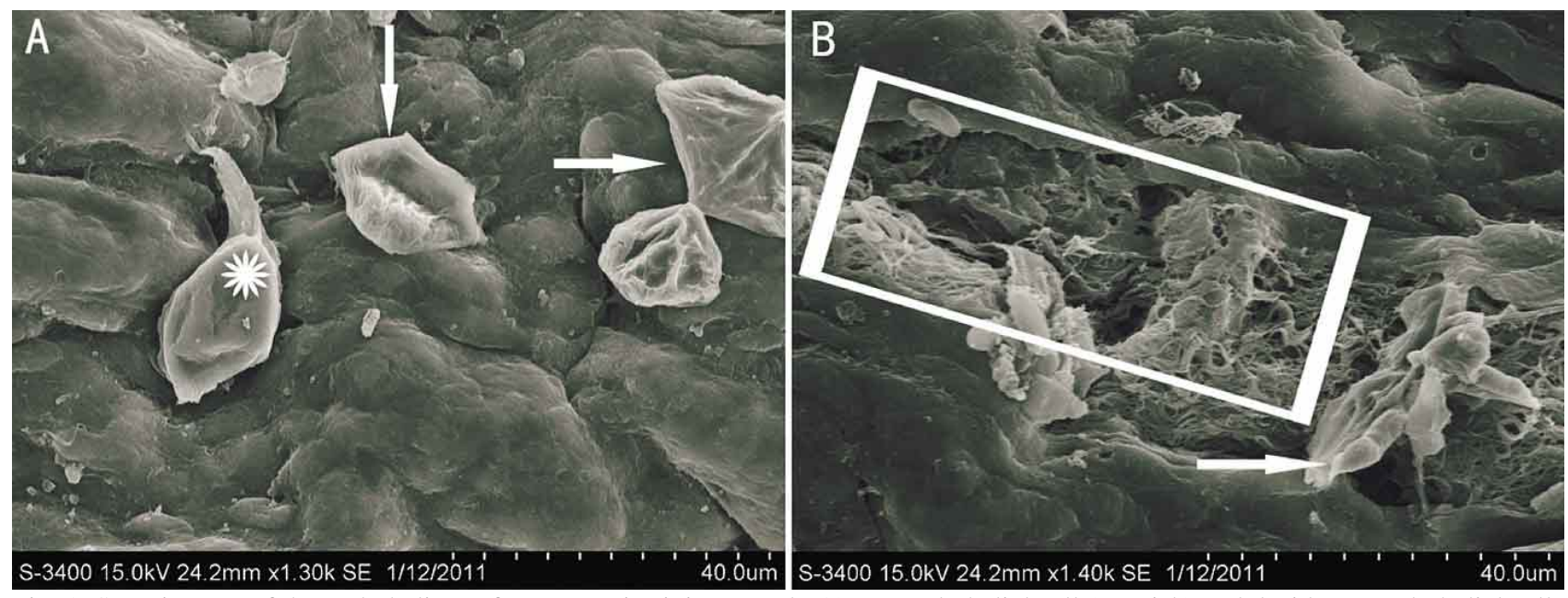

Fig. 1. SEM images of the endothelium of a. coronaria sinistra trunk: A) Neoendothelial cell (asterisk) and deciduous endothelial cells (arrowhead) located in the surface of the endothelium. B) The exposure of underlying collagen fibrils (inside of rectangular box) and deciduous endothelial cells (arrowhead) were visible.
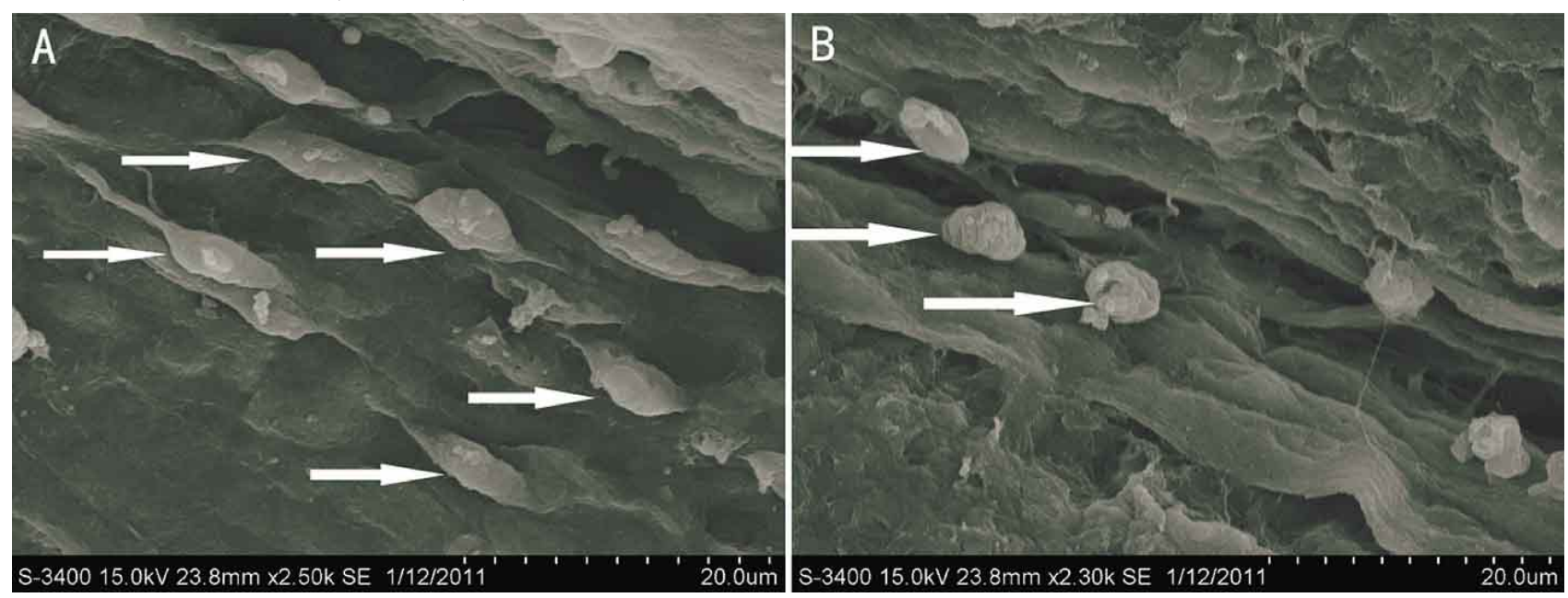

Fig. 2. SEM images of endothelium of ramus circumflexus of a coronaria sinistra. A) shows protuberant endothelial cells (arrowhead); B) shows platelets (arrowhead) and gap of endothelium (asterisk). 
As a main branch of a. coronaria dextra, ramus interventricularis subsinuosus displays a feature that it is separated by a few of grooves. Besides platelets sticking to the endothelium are visible (Fig. 5A and 5B).
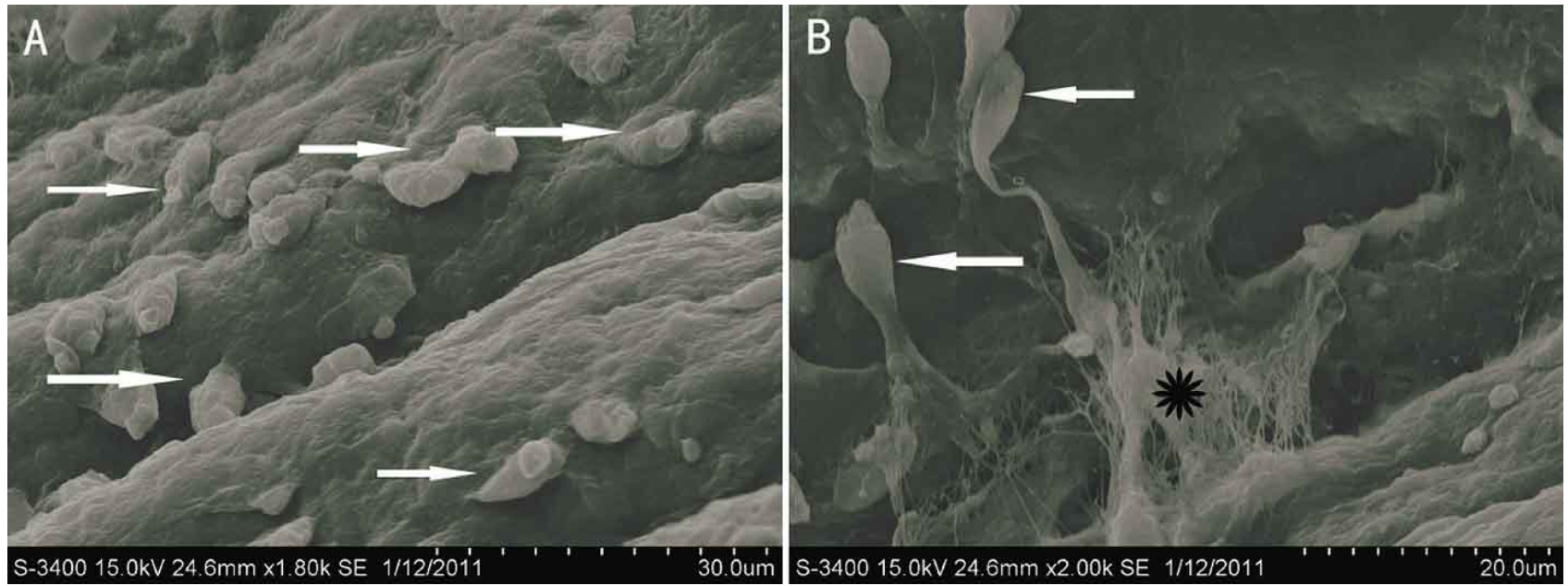

Fig. 3. SEM images of endothelium of ramus interventricularis paraconalis. A) shows a large number of endothelial cells whose nuclear are protuberant (arrowhead). B) shows collagen (asterisk) and endothelial cells (arrowhead).

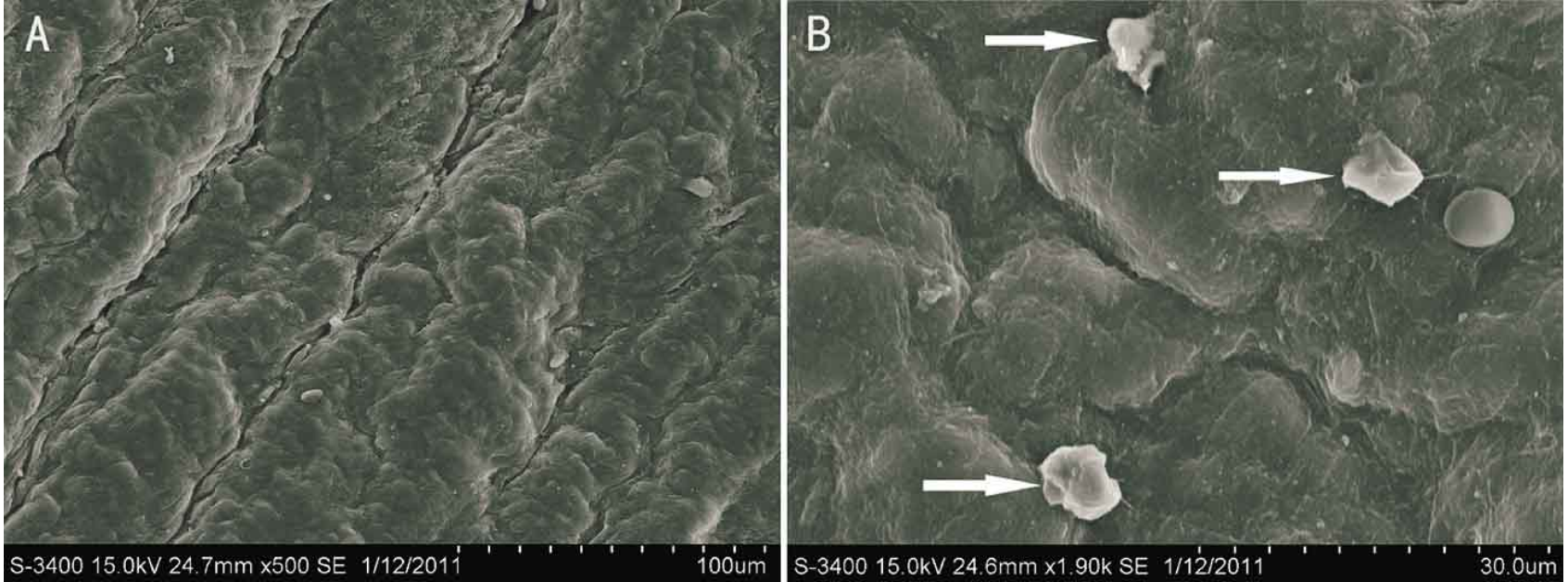

Fig. 4. SEM images of endothelium of a. coronaria dextra trunk: A) shows the endothelium. B) shows endothelial cells (arrowhead).
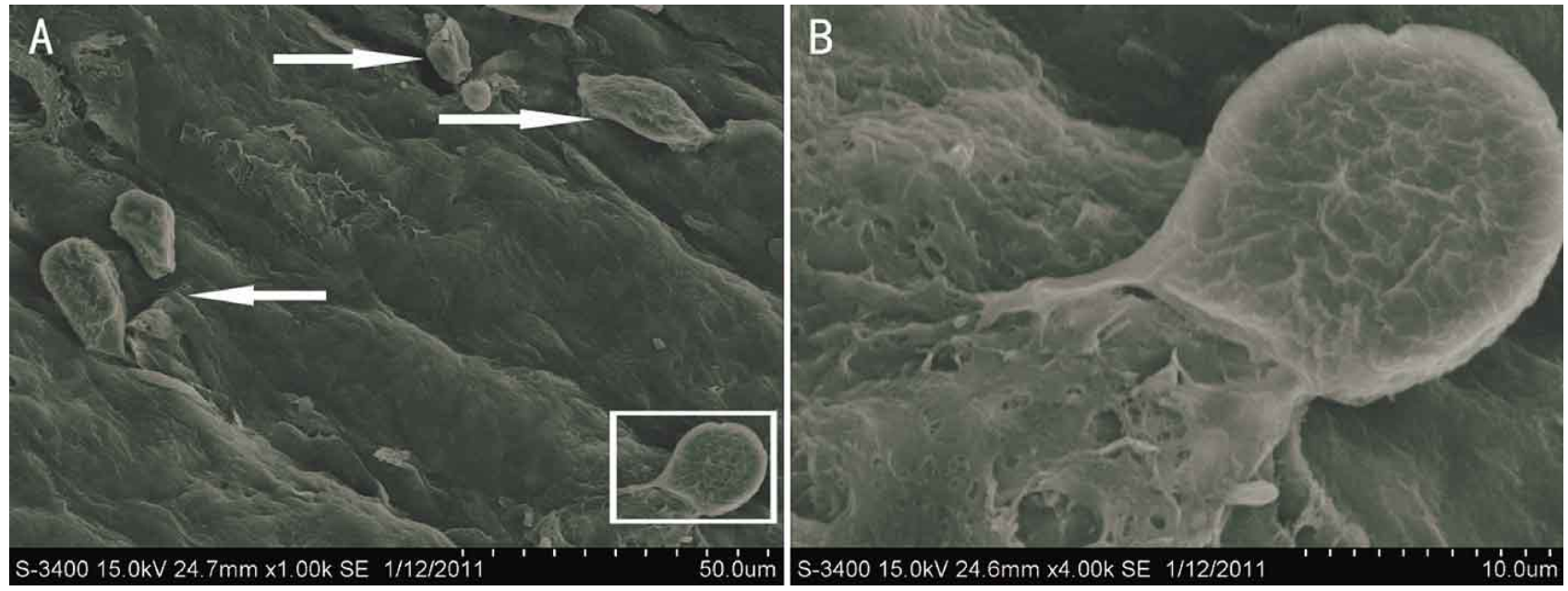

Fig. 5. SEM images of endothelium of ramus interventricularis subsinuosus: A) shows leukocytes existing in the surface of endothelium (arrowhead). B) is the magnification area of pane in Fig. 5A. 


\section{DISCUSSION}

Our previous study showed that branches of a.coronaria sinistra in Bactrian camels not only supply atrium sinistrum, ventriculus sinister and the adjacent part of ventriculus dexter, but also most parts of interventricular septum (Yuan et al., 2010). So the amount of blood that runs in the a. coronaria sinistra is greater than that in a. coronaria dextra. This means a. coronaria sinistra bears more powerful turbulent blood flow than that of a. coronaria dextra. This feature may be related to special endothelial structure of coronary arteries. In this study, using SEM technique, we presented a large number of endothelial cells protruding into luminal surface of a. coronaria sinistra that were found. The endothelium of a. coronaria dextra is relatively smooth compared to a.coronaria sinistra. Just few endothelial cells protruded into luminal surface of the vessel. Such unique structure might be an adaptation to help the camel to survive in a hot and dry climate.

The camel has the highest blood glucose level among all ruminants (Abdel-Fattah et al., 1999). Hyperglycemia as a pathological trigger, can activate endothelial cells and induce endothelial dysfunction. Endothelial dysfunction is an early event in the development of atherogenesis. Meanwhile, the camel can survive long periods even after more than 40 $\%$ loss of its body hydration and drink as much as $57 \mathrm{~L}$ of water in a short period of time. Such rapid rehydration can cause death to other mammals (Warda et al., 2014). Special ultrastructure of endothelial cells in coronary arteries may be related to these features of such species. We speculate that protuberances in luminal surface of coronary artery in Bactrian Camel may increase the absorption area for blood glucose and regulate blood flow velocity and volume to reduce the direct damage in the endothelium.

The luminal surface of a.coronaria sinistra was covered by impaired endothelium. The exposure of underlying collagen fibrils was visible in region of endothelial damage. In these regions there were also signs of proliferation and migration of endothelial were sometimes detected. However, the luminal surface of a. coronaria dextra was covered by intact endothelium. Endothelial cell injury is considered to play a critical role for development and progression of atherosclerosis (Krankel et al., 2014). There was only one case that reported camels were diagnosed positive for spontaneous atherosclerosis (Ezzi \& Zakarian, 1979). The reason why camels were rare diagnosed for atherosclerosis may be the complications of atherosclerosis were not present. Besides, it is possible the endothelium of the coronary artery in camels have the special abilities such as a substantially faster repair and replacement response in order to maintain endothelial integrity and function.

Platelets sticking to the endothelium were found. Their activation can alter the properties of leukocytes, endothelial cells and other vascular cells (Smyth et al., 200). They play an important part in cellular effectors of inflammation in vascular diseases (Rondina et al., 2013). They are first responders in vascular injury and endothelial disruption. Meanwhile, camel platelets are resistant to heat, which may help protect them from the effects of extreme body temperature and dehydration (Al Ghumlas et al., 2008).

The unique structure of the endothelium of coronary arteries might be related to the reason why camels were rarely diagnosed for cardiovascular diseases. A better understanding of the endothelium ultrastructure of coronary arteries may provide novel opportunities for therapeutic interventions of Bactrian camel cardiovascular diseases.

\section{ACKNOWLEDGMENTS}

We thank the slaughter house of the Right Alasan Banner Food Company (Inner Mongolia, China) for supplying hearts of Bactrian camels. Conflict of Interest: All authors declare that we have no conflict of interest.

YUAN, G.; PAN, Y.; LI, H. \& WANG, J. Características ultraestructurales del endotelio de las arterias coronarias en el camello bactriano (Camelus bactrianus). Int. J. Morphol., 34(1):280-284, 2016.

RESUMEN: Las células endoteliales de los vasos sanguíneos juegan un rol esencial en la regulación de las funciones endoteliales manteniendo el tono vascular, modulando la homeostasis y previniendo la trombogénesis. En la investigación se utilizó un microscopio electrónico de barrido, revelando las características estructurales de las células endoteliales de los vasos coronarios de los camellos bactrianos. Los resultados indican que las células endoteliales estaban distribuidas a lo largo de la dirección de flujo. En distintas partes de la arteria coronaria existen diferencias en el grado de proyección de la morfología y de la superficie de la cavidad de dichas células. La superficie luminal de la arteria coronaria izquierda y la arteria coronaria derecha estaban cubiertas por endotelio deteriorado e intacto, respectivamente. Se observó adhesión de leucocitos y plaquetas en la superficie de las células endoteliales.

PALABRAS CLAVE: Células endoteliales; Camello bactriano; Arteria coronaria; Ultraestructura. 


\section{REFERENCES}

Abdel-Fattah, M.; Amer, H.; Ghoneim, M. A.; Warda, M. \& Megahed, Y. Response of one-humped camel (Camelus dromedarius) to intravenous glucagon injection and to infusion of glucose and volatile fatty acids, and the kinetics of glucagon disappearance from the blood. Zentralbl. Veterinarmed. A, 46(8):473-81, 1999.

Al-Ani, F. K. Camel Management and Diseases. In: Al-Ani, F. K. (Ed.). Domestication, Distribution and Population. Jordan, AlSharq Printing Press, 2004. pp.1-24.

Al Ghumlas, A. K.; Abdel Gader, A. G.; Hussein, M. F.; Al Haidary, A. \& White, J. G. Effects of heat on camel platelet structure and function-a comparative study with humans. Platelets, 19(3):163-71, 2008

Bekele, T. Studies on the respiratory disease 'sonbobe' in camels in the eastern lowlands of Ethiopia. Trop. Anim. Health Prod., 31(6):333-45, 1999.

Chuluunbat, B.; Charruau, P.; Silbermayr, K.; Khorloojav, T. \& Burger, P. A. Genetic diversity and population structure of Mongolian domestic Bactrian camels (Camelus bactrianus). Anim. Genet., 45(4):550-8, 2014.

Ezzi, A. \& Zakarian, B. A survey on spontaneous atherosclerosis of camels (Camelus dromedarius) in Iran. Trop. Anim. Health Prod., 11(2):102-5, 1979.

Fowler, M. E. Medicine and Surgery of Camelids. $3^{\text {rd }}$ ed. Ames (Iowa), Wiley-Blackwell, 2010. pp.423-7.

Ji, R.; Cui, P.; Ding, F.; Geng, J.; Gao, H.; Zhang, H.; Yu, J.; Hu, S. \& Meng, H. Monophyletic origin of domestic bactrian camel (Camelus bactrianus) and its evolutionary relationship with the extant wild camel (Camelus bactrianus ferus). Anim. Genet., 40(4):377-82, 2009.

Krankel, N.; Luscher, T. F. \& Landmesser, U. Novel insights into vascular repair mechanisms. Curr. Pharm. Des., 20(14):2430$8,2014$.

Rondina, M. T.; Weyrich, A. S. \& Zimmerman, G. A. Platelets as cellular effectors of inflammation in vascular diseases. Circ. Res., 112(11):1506-19, 2013.

Smyth, S. S.; McEver, R. P.; Weyrich, A. S.; Morrell, C. N.; Hoffman, M. R.; Arepally, G. M.; French, P. A.; Dauerman, H. L.; Becker, R. C. \& 2009 Platelet Colloquium Participants. Platelet functions beyond hemostasis. J. Thromb. Haemost., 7(11):1759-66, 2009.

Warda, M.; Prince, A.; Kim, H. K.; Khafaga, N.; Scholkamy. T.; Linhardt, R. J. \& Jin, H. Proteomics of old world camelid (Camelus dromedarius): Better understanding the interplay between homeostasis and desert environment. J. Adv. Res., 5(2):219-42, 2014.

Yang, Q.; Yu, C. M.; He, G. W. \& Underwood, M. J. Protection of coronary endothelial function during cardiac surgery: potential of targeting endothelial ion channels in cardioprotection. Biomed. Res. Int., 2014:324364, 2014.

Yuan, G.; Ma, J.; Ye, W.; Bai, Z. \& Wang, J. Macroanatomy of coronary arteries in Bactrian camel (Camelus bactrianus). Vet. Res. Commun., 33(4):367-77, 2009.

Yuan, G. Q.; Xu, Y. Q.; Yang, C.; Bai, Z. T.; He, J. B.; Shao, B. P.; Zhao, S. T. \& Wang, J. L. The arterial vascularization of septum interventriculare in Bactrian camel (Camelus bactrianus). $J$. Camel Pract. Res., 17(2):161-6, 2010.

\section{Correspondence to: \\ Jianlin Wang \\ School of Life Science \\ Lanzhou University \\ 730000 Lanzhou \\ Gansu \\ CHINA}

Email: jlwang@lzu.edu.cn

Received: 12-08-2015

Accepted: 19-10-2015 